> Tips om medisinsk litteratur, andre bøker, filmer og elektroniske medier

som bør anmeldes, sendes tidsskriftet@legeforeningen.no

\section{Grundig og god fortolkning av medikalisering}

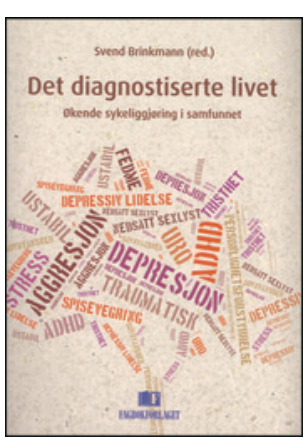

Svend Brinkmann, red.

Det diagnostiserte livet

$\emptyset$ kende sykeliggjøring i samfunnet. $292 \mathrm{~s}$, ill.

Bergen: Fagbokforlaget, 2015. Pris NOK 439

ISBN 978-82-321-0432-1

Svend Brinkmann er redaktør for denne antologien av tekster hvor man analyserer medikalisering og sykeliggjøring i moderne samfunn. Målgruppen er primært aktører innen akademisk psykologi og samfunnsvitenskap, men også terapeuter innen medisin og psykologi. Her er mange tekster som vil glede spesielt terapeuter med interesse for refleksjon om de individuelle og samfunnsmessige komplikasjonene av diagnostisk og terapeutisk innsats. Boken kan også leses av den opplyste allmennhet, selv om noen bidrag inneholder fagtermer som ikke er selvforklarende.

Brinkmann skriver selv det første og siste kapitlet. På den måten rammer han stoffet inn ved å gi et historisk bakteppe og avslutningsvis å tegne et kart over dagens dilemmaer og utfordringer. Den første delen inneholder seks perspektiver på sykeliggjøringen som fenomen. Her finner vi filosofiske analyser, sosiologiske analyser, det idéhistoriske perspektivet og ikke minst en interessant analyse av terapeutisk forståelse i valget mellom et essensialistisk (sykdom forstått som objekt) og et dialogisk eller kontekstuelt (sykdom forstått som invitasjon og interaksjon) sykdomssyn.

I den andre delen gir forfatterne en fremstilling av diagnostiske praksiser og kategorier som er aktuelle i vår samtid: $\mathrm{AD} / \mathrm{HD}$, fedme, depresjon (rettere sagt tristhet), avhengighetstilstander og kroppslige helseplager. Et sentralt omdreiningspunkt for de forskjellige temaene er Ian Hackings forståelse av hvordan sykdom konstrueres sosialt. Når vi prøver å fange disse fenomenene som diagnostiske, objektive kategorier, engasjeres vi i en aktivitet som kan sammenliknes med forsøk på å fange vår egen hale. Mennesker er selvfortolkende og meningssøkende subjekter som har behov for identiteter. Derfor blir diagnosene gjenstand for grenseløs inflasjon. Mange andre perspektiver analyseres også, for eksempel individualisering, forbruksideologi, normoppløsning, feminisering av pedagogikken og sosial ustabilitet - for å nevne noen få.

Jeg har i forskjellige sammenhenger kritisert den sosiologiske og sosialpsykologiske kritikken mot medikalisering og terapeutisering for å mangle en alternativ etisk horisont. Selv om jeg kunne ønsket at Brinkmann hadde lagt større vekt på det, finner vi anslag til alternativer i disse tekstene. Jeg sikter spesielt til kapitlet om å forstå sykdom som invitasjon og dialog og kapitlet om avhengighetstilstander. Det er ingen tilfeldighet at biologen og antropologen Gregory Bateson (1904-80) er en sentral referanse for begge disse kapitlene. Hans analyse av hvordan vi er innvevd i økologiske fellesskap, og hvor nødvendig det er å forstå oss selv som tilhørende i noe større enn oss selv, er sentralt for forfatterne av disse delene. For Bateson og undertegnede er det naturlig å forstå sykeliggjøringen som uttrykk for at vi har gjort oss hjemløse i en verden hvor tilhørigheten i en hellighetsdimensjon er en livsbetingelse.

Men for all del: Boken anbefales!

Eivind Meland

Professor, Institutt for global helse og samfunnsmedisin

Universitetet i Bergen

\section{Aktuelt og velskrevet om genetikk}

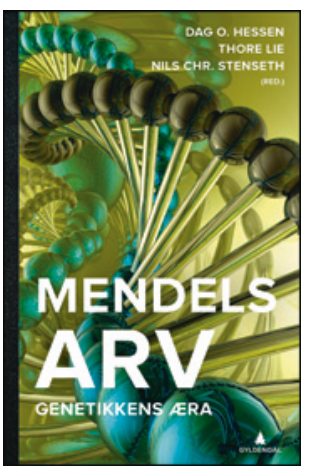

Dag O. Hessen, Thore Lie,

Nils Christian Stenseth, red.

Mendels arv

Genetikkens æra. 435 s, ill. Oslo: Gyldendal, 2015. Pris NOK 449

ISBN 978-82-05-45818-5

Denne boken blir utgitt i forbindelse med at det er 150 år siden Gregor Johann Mendel (1822-84) presenterte resultatene av sine krysningsfors $ø \mathrm{k}$ med erteplanter. I forordets leseveiledning står det at boken ikke skal være en heldekkende bok om genforskning og arv, men en bok som alle skal kunne ha utbytte av å lese.

De tre delene, Grunnlaget, Innsikten og Anvendelsen, har alle en kort innledning. Til sammen er det 17 kapitler som er skrevet av 21 forfattere med svært forskjellig bakgrunn. Hvert kapitel kan leses som en selvstendig enhet, men kravet til forhåndskunnskap for de forskjellige kapitlene varierer. Illustrasjonene er gode, med enkle figurer og vakre fotografier fra naturens mangfold.

Temaene som blir tatt opp, er relevante for folk flest, slik som vitenskapshistorie, biologisk mangfold, matproduksjon, gener og kreft, folkehelsevitenskap og genteknologi og etikk. Andre temaer, for eksempel metagenomikk, er nok mindre kjent, men spennende og viktige. Metagenomikk refererer til studier av genetisk materiale isolert fra en miljøprøve, for eksempel tarm, og hva dette kan brukes til i medisinen. Forfatterne tar også opp temaer som kan være kontroversielle, for eksempel diskusjonen rundt TV-programmet Hjernevask.

Bare tre av forfatterne er leger, og de fleste temaene er ikke direkte knyttet til medisinsk genetikk. Boken er likevel aktuell for leger fordi genetikk er noe alle leger nå må forholde seg til. Et godt eksempel er epigenetikk som «alle» snakker om, men som de færreste vet hva er. I kapitlet Epigenetikk - hadde Lamarck rett? kan vi enten lese hele den omfattende gjennomgangen av litteraturen, eller nøye oss med den klare konklusjonen. Lamarck hadde ikke rett: «Nyere forskning kan så langt ikke vise at ervervede «epigenetiske» egenskaper nedarves stabilt over flere generasjoner.» Den som vil vite mer om hva genomsekvensering innebærer, kan følge historien om hvordan en av forfatterne selv opplevde å få sitt genom sekvensert.

Jeg er enig med redaktørene $i$ at alle bør kunne ha utbytte av å lese i denne glimrende boken. Derfor anbefaler jeg den til alle leger som vil følge med på den lynraske utviklingen som nå finner sted innen genetikken.

Karen Helene Ørstavik

Professor emerita, Institutt for klinisk medisin Universitetet i Oslo 